\title{
Biology Students' Cognitive Structures about Basic Components of Living Organisms
}

\author{
Murat Özarslan ${ }^{1 *}$, Gülcan Çetin ${ }^{2}$ \\ ${ }^{1}$ Department of Biology, Ministry of National Education, Kocaeli, Turkey, ${ }^{2}$ Department of Mathematics and Science Education, Biology Education, \\ Necatibey Faculty of Education, Balıkesir University, Balıkesir, Turkey
}

*Corresponding Author: muratozarslan14@gmail.com

\section{ABSTRACT}

The aim of this study was to investigate $9^{\text {th }}$ grade biology students' cognitive structures about the basic components of the living organisms and association between the concepts forming these basic components. Participants consisted of $509^{\text {th }}$ grade biology students in two secondary schools in the northwest of Turkey. Data were collected by the word association test (WAT) and the questionnaire of writing sentence (QWS). The WAT is comprised 16 key concepts related to Biology: Inorganic compounds, organic compounds, acid, base, salt, water, mineral, carbohydrate, fat, protein, enzyme, vitamin, nucleic acid, DNA, RNA, and ATP. For the analysis of the WAT, the frequencies of the number of words and the number of word varieties about each key concept in the WAT were counted. Mind maps were then drawn with the help of the technique of breakpoint according to represent the WAT data. The QWS was analyzed by content analysis method. The study results showed that the existing conceptual relationships in the mind maps of the students were actively used in the sentences in the students' written QWS. The experiences of the students such as life, laboratory studies, and the sharing of teachers in lessons on healthy diet were effective in the cognitive structures of the students. However, the existence of significant deficiencies and some non-scientific relationships in the students' cognitive structures on basic components of living organisms were detected.

KEY WORDS: basic components of living organisms; cognitive structure; questionnaire; secondary school education; word association test

\section{INTRODUCTION}

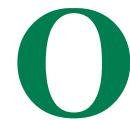

ne of the important improvements in science education has been the constructivist approach that focuses attention on ideas of knowledge construction in the mind, how knowledge is constructed, and how people learn (Kılıç, 2001; Durmuş, 2001). This approach can be analyzed as cognitive, social, or radical constructivism. Radical and social constructivism is not part of this study. Cognitive constructivists are influenced by Piaget with explaining how knowledge is constructed (Adigüzel, 2009). Piaget claimed that knowledge is constructed with the help of complex and integrated ways. Piaget further argued that during the period in which knowledge is constructed and learning is acquired connections in the mind are constantly trying to be built (Solso et al., 2009).

An individual who can fulfill meaningful learning has more complex knowledge networks in his or her cognitive structure and their remembering is fulfilled more easily due to an increase of the connections between concepts (Bahar et al., 2006). The factors such as knowledge that an individual constructed before, the way how prior knowledge is constructed, the perception and experiences of individuals, and also their thoughts, and their interaction with the environment take an active role in the construction of new knowledge (K1lıç, 2001; Demirbaş and Ertuğrul, 2014; Durmuş, 2001; Stears and Gopal, 2010; Şimşek, 2004).
The center where knowledge is constructed and learning is carried out cognitively by human beings is known as a person's "memory." In cognitive psychology, human memory consists of two storages: Short-term memory (STM and working memory) and long-term memory (LTM). The work and functions of these memories were enlightened and put forward as a model by Baddeley (1992). In this model, STM is a system in which knowledge is kept and organized for a short time. However, LTM is known as a place where knowledge is kept for a long time. In this memory, knowledge forms a construction in the shape of a connected network (Schunk, 2009).

Many different models that try to explain the connection between knowledge and the representation of knowledge in the mind. According to one of these models called "Network Model," semantic memory is originated from a wide conceptual network, which is linked to each other with a line of associations (Schunk, 2009). In this model, it should be noted that lexical proximity and lexical distance have an effect on the connection of knowledge. Accordingly, the closer two concepts are, the stronger the connection they have and the faster it is to get an answer related to these two concepts through recollection (Bahar and Özatl1, 2003). Thus, a student's answer to any key concept in LBM reveals the connections of the concepts in cognitive structures and it may also reveal lexical proximity (Tongaç, 2006). 


\section{Word Association Test (WAT)}

Many techniques such as written examinations, short answer questions, structured grids, assessments, and evaluations are used with the aim of discovering the cognitive structure. One of the basic points of these techniques makes it possible to determine whether students' cognitive structures, their relations with concepts, and the association between these concepts is adequate (Bahar et al., 2006). WAT is one of the techniques that can be used for this purpose (Bahar et al., 1999; Bahar and Özatlı, 2003; Özatl1, 2006; White and Gunstone, 1992).

WAT informs about the number and variety of students' answers to key concepts, the complexity of the associations among concepts, their numbers, and their understanding on the subject. Furthermore, the number of the answers that students give about the concept is regarded as a symbol for an individual's level of understanding of the concept. The unrelated concepts are thought to be meaningless by that individual (Atasoy, 2004; Bahar et al., 1999). WAT can be used as both an assessment and evaluation tool as well as a diagnostic tool (Bahar and Özatl1, 2003; Bahar et al., 2006). Currently, WAT is one of the most common tests and is used in a variety of subjects. For instance, WAT has been used to determine the cognitive structures related to concepts such as genetics (Bahar et al., 1999), basic components of living organism (Bahar and Özatl1, 2003), urinary system (Özatl1, 2006), circulatory system (Bahar and Tongaç, 2009), respiration and transport and circulatory systems (Kurt et al., 2013), living things (Kurt, 2013), ecological concepts (Yücel and Özkan, 2015), decomposition (Schizas et al., 2013), biodiversity (Uzun et al., 2010), dangerous animals (Çardak, 2009), structure of atom (Nakiboğlu, 2008), mole, mixture, and chemical equation (Lee et al., 2001), solar system and space (Ercan et al., 2010), accounting concepts and architecture building material (Perker, 2011), scientific method (Gulacar et al., 2014), and education (Zan et al., 2015).

Bahar and Özatlı (2003) studied the basic components of living organisms at the secondary education level and used WAT to indicate students' cognitive structures. In their study, students' prior knowledge was expanded on a wide area that was not closely related to the subject of study. In addition, their students' word association post-test results had more scientific and varied answers than their pre-test results. Students established associations such as vitaminfruit, vitamin-vegetables, Vitamin-A, B, C, and D, acid-cola, vitamin-medicine, water-enzyme, DNA-test, DNA-blood, and gene-human. Nevertheless, it was seen that some necessary connections between concepts were not formed. In some connections, unscientific relations were observed such as DNA-ATP, RNA-ATP, vitamin-energy, mineral-vitamin, carbohydrate-air, RNA-test, and water-energy (Bahar and Tongaç 2009). In her study, Özatlı (2009) used WAT to research students' cognitive structures about the urinary system and she concluded that the experimental group of the students improved their connections between key concepts much more than the control group.
Cognitive structure is related to success and many factors that are directly connected to success. For instance, there is a strong relationship between students' prior knowledge, their cognitive structures, and their performance at problem solving (Gussarsky and Gorodetsky, 1988; Kempa and Nicholls, 1983; Lee et al., 2001; Solaz-Portolés and Lopez, 2007). A meaningful relationship between students' cognitive structures and their science success has been reported (Ring and Novak, 1971; Tsai, 1988). Kempa (1991) indicated that students' lack of knowledge in their mind, the incorrect or inappropriate connections between knowledge parts, the lack of important connections between knowledge parts, or the existence of incorrect or unrelated knowledge may cause difficulties in learning.

For students to learn meaningfully instead of memorizing, they need to relate new knowledge with their prior knowledge. The meaningful structuring of knowledge in students' mind might affect their future learning. The unit "basic components of living organisms" in $9^{\text {th }}$ grade biology course is one of the most important units in Biology, since the concepts that will be learned in this unit are regarded as prior knowledge for many topics such as protein synthesis, systems, and inheritance (Sinan et al., 2006). Setting the associations between concepts and cognitive structures related to the basic components of living organisms can be an important step for future learning.

With the help of the determination of students' cognitive structure about the basic components of living organisms, inaccuracies, and incorrect relations experienced in structuring concepts on the subject can be identified. The subject at targeted level and requirements as well as crucial points for meaningful learning in shaping of the cognitive structure of the students can be realized. To supply the reorganization of necessary instructional designs for meaningful learning may give ideas to researchers. Finally, it is expected to provide an important contribution to the literature.

\section{METHOD}

\section{Problem}

What is the relationship between the cognitive structures of $9^{\text {th }}$ grade biology students about the basic components of the living organisms and the concepts forming these structures?

\section{Participants}

Participants consisted of $509^{\text {th }}$ grade biology students in two secondary schools in the northwest of Turkey. They were chosen according to convenience sampling method. The reason why participants were chosen with this sampling method was that exemplification could be reached easily and the implementation could be fulfilled regarding the restrictions such as time, money, and labor force (Büyüköztürk et al., 2013).

\section{Data Collection and Data Analysis}

In this study, two data tools were used: WAT and questionnaire of writing sentence (QWS). They were used to investigate the 
students' cognitive structures related to the basic components of living organisms and to determine the associations between the concepts forming these structures.

\section{WAT}

The WAT consists of 16 key concepts from the basic components of living organisms in $9^{\text {th }}$ grade biology course. These are inorganic compound, organic compound, acid, base, salt, water, mineral, carbohydrate, fat, protein, enzyme, vitamin, nucleic acid, DNA, RNA, and ATP. To determine these concepts all of the important concepts related to basic components of living organisms in $9^{\text {th }}$ grade biology course were listed. Then, the 16 key concepts necessary for this unit were selected by the study's authors. The test was prepared as a booklet in which each key concept was written on different pages 10 times one under the other (Bahar and Özatlı, 2003).

Before the application of the WAT, this technique was introduced to the students and scaffold with some simple current concepts for the students to familiarize themselves this technique so as not to have any problem during the practice. Next, the essential study was carried out. For the WAT, $30 \mathrm{~s}$ were given to the students for each key concept. In this period, the students were asked to write concepts that come to their mind related to each key concept (Bahar and Özatll, 2003; Bahar et al., 1999). After each $30 \mathrm{~s}$, the students were asked to prepare for the next key concept. Thus, the questionnaire completion was limited to $16 \mathrm{~min}$.

In the WAT analysis, the students' answer sheets were given numbers from 1 to 50. Each key concept in the WAT was analyzed separately. All of the words that the students wrote about each one of key concepts were recorded, how many different words the students used, and which key concept these words related to were noted. Results were presented in frequency tables (Table 1). Using Table 1's information, mind maps were then drawn (Figures 1-5). Mind maps were prepared separately from the highest frequency to the lowest. While creating the mind maps, the breakpoint technique (BP) was used (Bahar et al., 1999). In this technique, the most given answer for any key concept in the frequency table that is 3-5 below the word is used for the breakpoint. The answers over the frequency of this answer are written in the first part of a mind map. The comments and evaluations such as the associations between concepts which are in the highest map at BP as frequency have the strongest connections and the associations between concepts go down because of the decrease of frequencies at BP can be made.

The number of answer words given for each key concept was taken into consideration in this study, the highest frequency was $(f=35)$ fruit and vegetable related to the concept vitamin (see column vitamin, and line fruit/vegetable). Therefore, the highest frequency was 35 in Appendix 1. Therefore, BP was accepted as 30 . Then, the breakpoint was pulled down between certain maps and the process continued until all key concepts were visible in the mind maps (Bahar and Özatl1, 2003; Bahar and Tongaç, 2009; Nakiboğlu, 2008; Özatl1, 2006).
Table 1: Frequencies of number of words and word type counts for 16 key concepts in WAT

\begin{tabular}{lcclcc}
\hline KC & WTC (f) & NW (f) & KC & WTC (f) & NW (f) \\
\hline $\begin{array}{l}\text { Inorganic } \\
\text { components }\end{array}$ & 27 & 158 & Fat & 41 & 198 \\
$\begin{array}{l}\text { Organic } \\
\text { components }\end{array}$ & 44 & 179 & Protein & 48 & 216 \\
Acid & 40 & 185 & Enzyme & 48 & 122 \\
Base & 30 & 149 & Vitamin & 41 & 177 \\
Salt & 35 & 135 & Nucleic acid & 41 & 172 \\
Water & 43 & 207 & DNA & 40 & 266 \\
Mineral & 45 & 168 & RNA & 40 & 190 \\
substance & & & & & \\
Carbohydrate & 49 & 203 & ATP & 32 & 153 \\
\hline KC: Key concept, NW: Number of words, WTC: Word type counts
\end{tabular}

\section{Fruit and Vegetable}

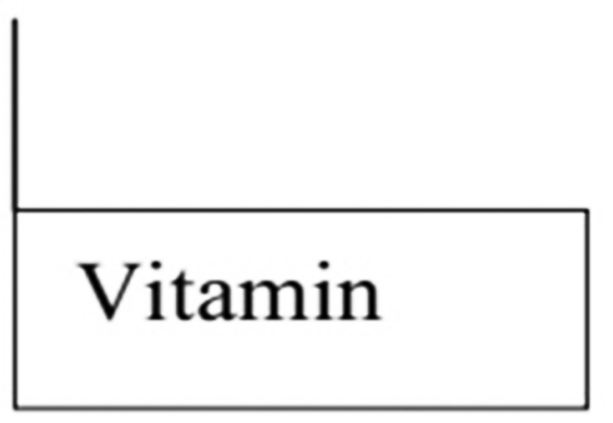

Figure 1: Mind map according to breakpoint 30-35

\section{QWS}

This questionnaire includes one question. The students were asked to write sentences about what they knew about each key concept found in the WAT. The aim here was to indicate the concepts that they built in their mind related to each key concept. During the period of writing about a topic, an individual needs to revise what he or she has structured in their mind, organize and choose it, and also transform chosen knowledge to letters and syllables and then to words and sentences (Kırbaş and Orhan, 2011; Onan, 2012). Questionnaire completion was limited to $16 \mathrm{~min}$.

Data were analyzed through the content analysis method. The students' answer sheets were given numbers from 1 to 50 . Then, all of the words that the students wrote in their sentences about each key concept (each key concept was regarded as a theme) were determined, and these words were coded as sub-themes in groups (Yıldırım and Şimşek, 2006). Frequencies of sub-themes were calculated, and they were presented in a table (Table 2).

A sample answer paper to both the WAT and QWS is provided (Appendix 2).

In the research, the reliability of the results of the WAT and QWS was sustained by the study's authors. Furthermore, raw 


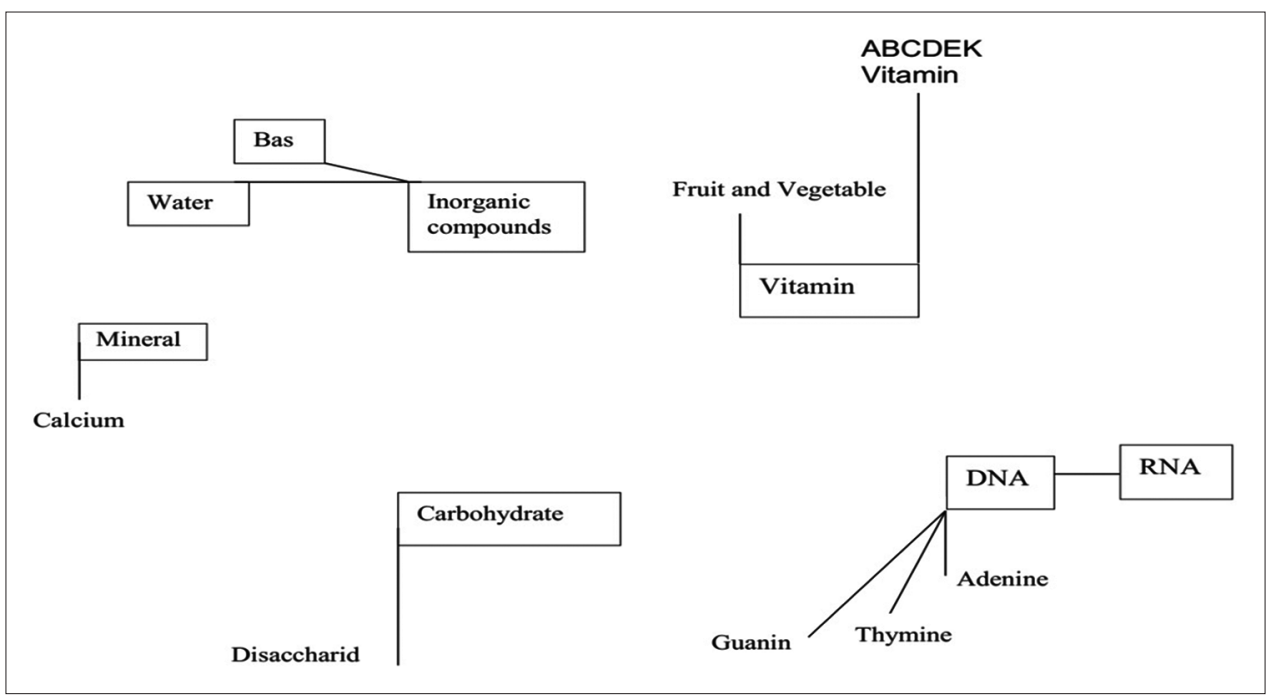

Figure 2: Mind map according to breakpoint 25-29

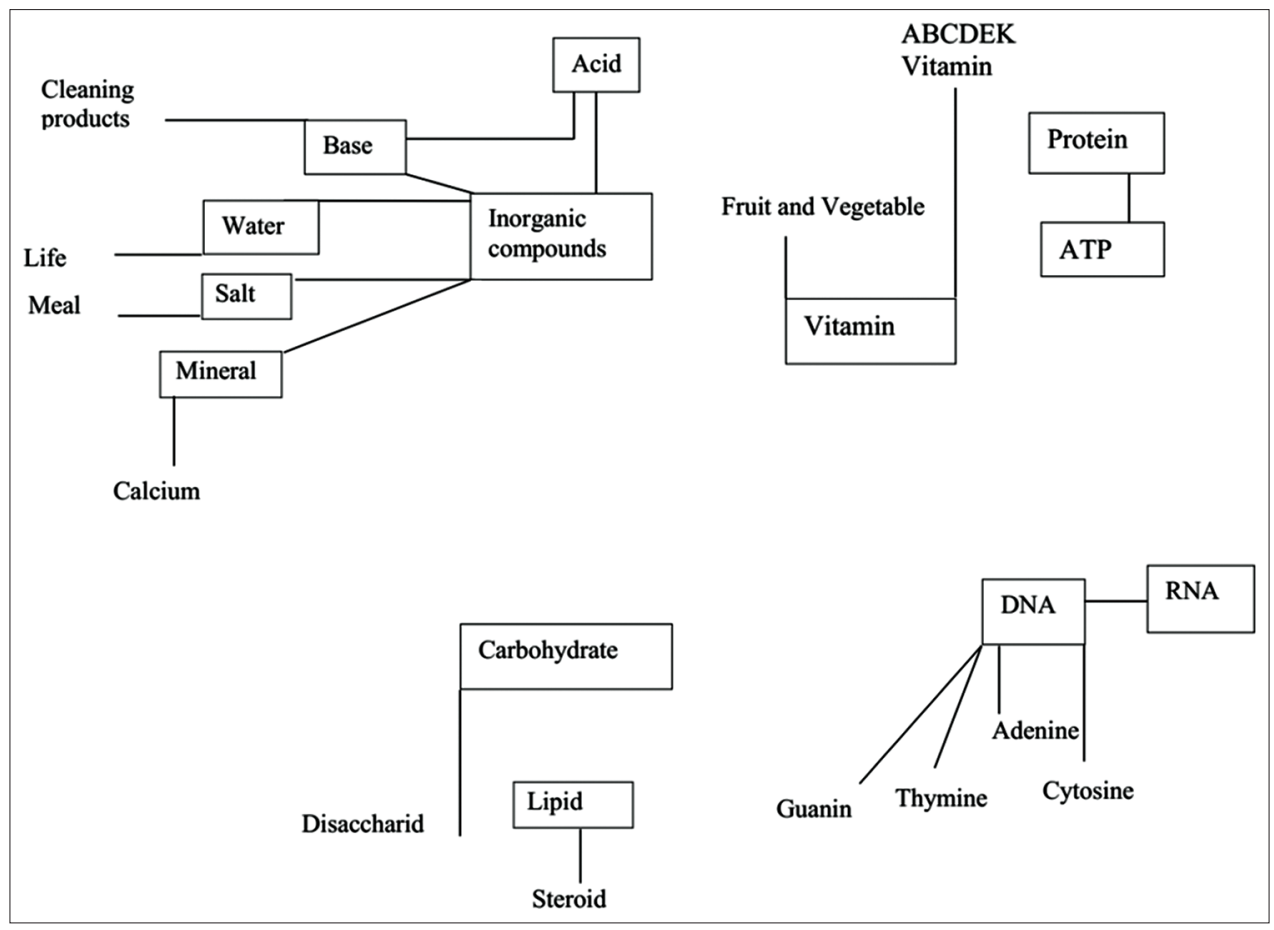

Figure 3: Mind map according to breakpoint 20-24

data and codes were kept by the researchers so as to be able to be examined by others.

\section{FINDINGS}

\section{Findings about WAT}

Table 1 presents that a number of words and word type counts for the 16 key concepts in the WAT. The students wrote 644word types and 2878 number of words for the 16 key concepts. The students used the concept carbohydrate (49) the most and inorganic compounds (27) the least according to the word type counts. The students wrote DNA the most frequently (266) and enzyme the least (122).
In Figures 1-5, mind maps were formed using the data of frequency table to indicate the associated relationships between concepts and the students' cognitive structures related to the basic components of living organisms are seen.

When the mind map is examined in Figure 1, the strongest relationship $\mathrm{BP}=35$ is vitamin-fruit/vegetable which occurs in daily life. Since healthy nourishment is one of the most essential units in biology and hygiene courses, this kind of strong relationship can be built in the students' cognitive structures.

In Figure 2, the number of key concepts increased for $\mathrm{BP}=$ 25-29 and 8 key concepts from 16 concepts became apparent. 


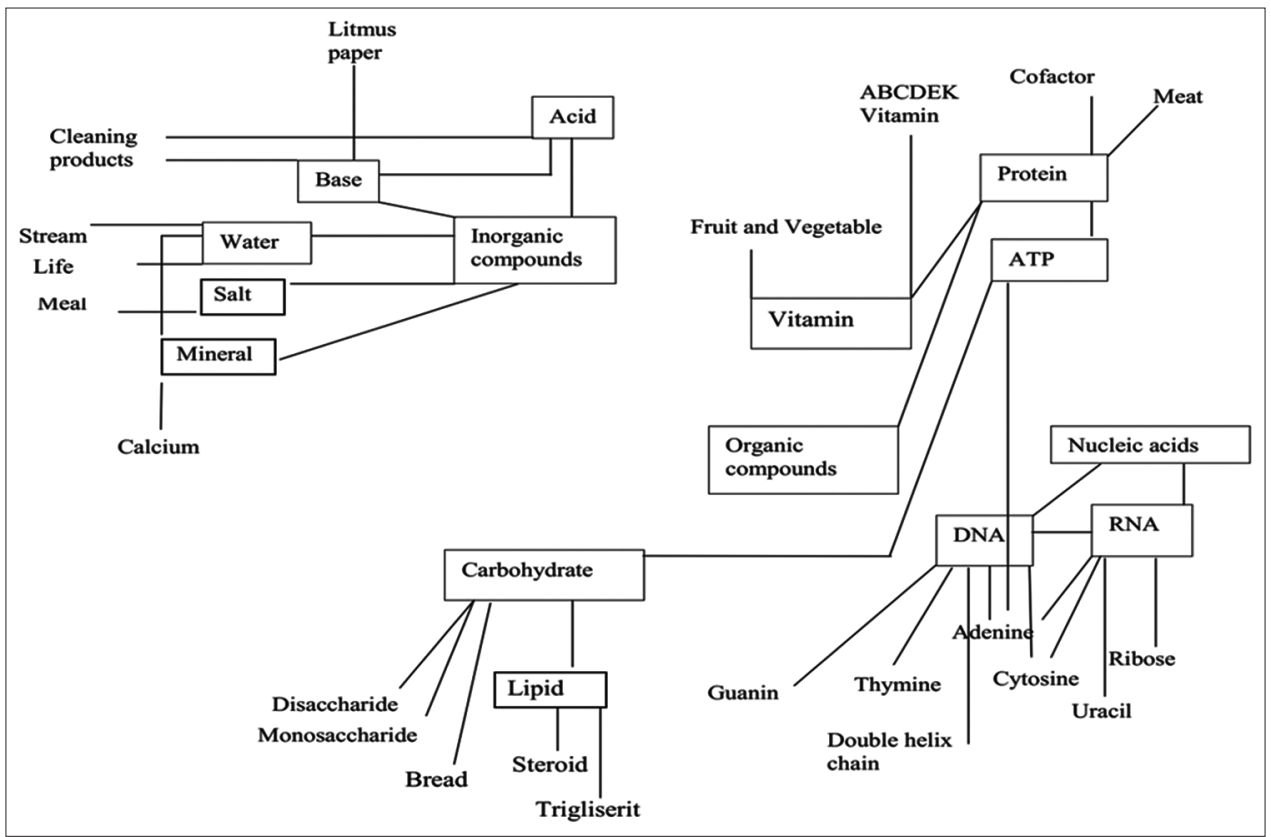

Figure 4: Mind map according to breakpoint 15-19

While there are 5 islets here, there is no relationship between them. However, each islet has a meaningful association in itself. In addition to the association between vitamin-fruit and vegetable, $\mathrm{A}, \mathrm{B}, \mathrm{C}, \mathrm{D}, \mathrm{E}$, and $\mathrm{K}$ Vitamins, mineral-calcium, DNA-RNA, DNA-guanine, adenine and thymine bases, inorganic compound-water, and inorganic compound-base concepts are noteworthy. The existence of parallel subjects in biology and hygiene courses and teaching the healthy nourishment with caution have an effect on the basis of the strong association between A, B, C, D, E, and K Vitamins concepts. Furthermore, the subject including the concepts related to DNA-RNA and DNA-guanine, adenine and thymine bases take place in science course and the associations improved by growing stronger with biology course. All of these meaningful associations can be regarded as a symbol for meaningful learning.

As seen in mind map in Figure 3, the number of key concepts increased with $\mathrm{BP}=20-24$ with 13 of the 16 key concepts evolved. In the previous frequency map ( $\mathrm{BP}=25-29)$, two of the three islets on the left are bonded on inorganic compoundmineral. However, the bond in Figure 3 demonstrates that the students regard minerals (for example, calcium) as inorganic compounds. The relationship between the key concepts inorganic compound-acid-base-water-salt-mineral increased; however, there was not any connection between the concepts carbohydrate-fat-vitamin-ATP-protein. From the associations between concepts, the associations such as base-cleaning products, water-life, and salt-meal are more visible. This is thought to be related to life. In other associations, the target connections increased in meaningful learning.

When the mind map is examined in Figure 4, for the map $\mathrm{BP}=15-19,15$ concepts from the 16 concepts are visible.
Two big islets were formed from these key concepts. Nevertheless, there are some disconnections between some of the students' knowledge. Associations between concepts such as base-litmus paper, which takes place in mind map, are thought to be very important. Experimental studies of the students are thought to be effective on these associations. The life of the students is also thought to be effective in forming the associations between water-river, protein-meat, meat products, carbohydrate-bread, and acid-cleaning products. Furthermore, the concepts of fat-steroid are more related to each other than the other concepts concerning the concept fat. The concept protein-cofactor has a strong association. Nonetheless, between the concepts DNA-ATP, unscientific associations are detected.

According to the mind map, in Figure 5, all 16 key concepts are visible for the map $\mathrm{BP}=10-14$. Meaningful associations between concepts increased more and more here. Two islets are bonded to each other in two ways with correct associations over acid-nucleic acid, acid-fruit, and vegetable. However, the completion of these associations in low frequency demonstrates that meaningful associations of the students were not strong. Base-pH $>7$, base-bitter, base-blue, acid-litmus, acid-cola, acid-lemon, acid-red, acid-harmful, acid-sour, acid-fruit and vegetable, and acid-salt are notable. Experience is an effective factor for the reason of this construction. Both out of school lives of the students and their laboratory applications play an active role in establishing these associations. Nevertheless, complex and meaningful associations were not generally established. For example, while there were 48 different word varieties for the key concept "enzyme," when the mind map was revised, only one association could be seen. The reason of this is thought to stem from the fact that the frequency of word varieties was low and the association of the concept 


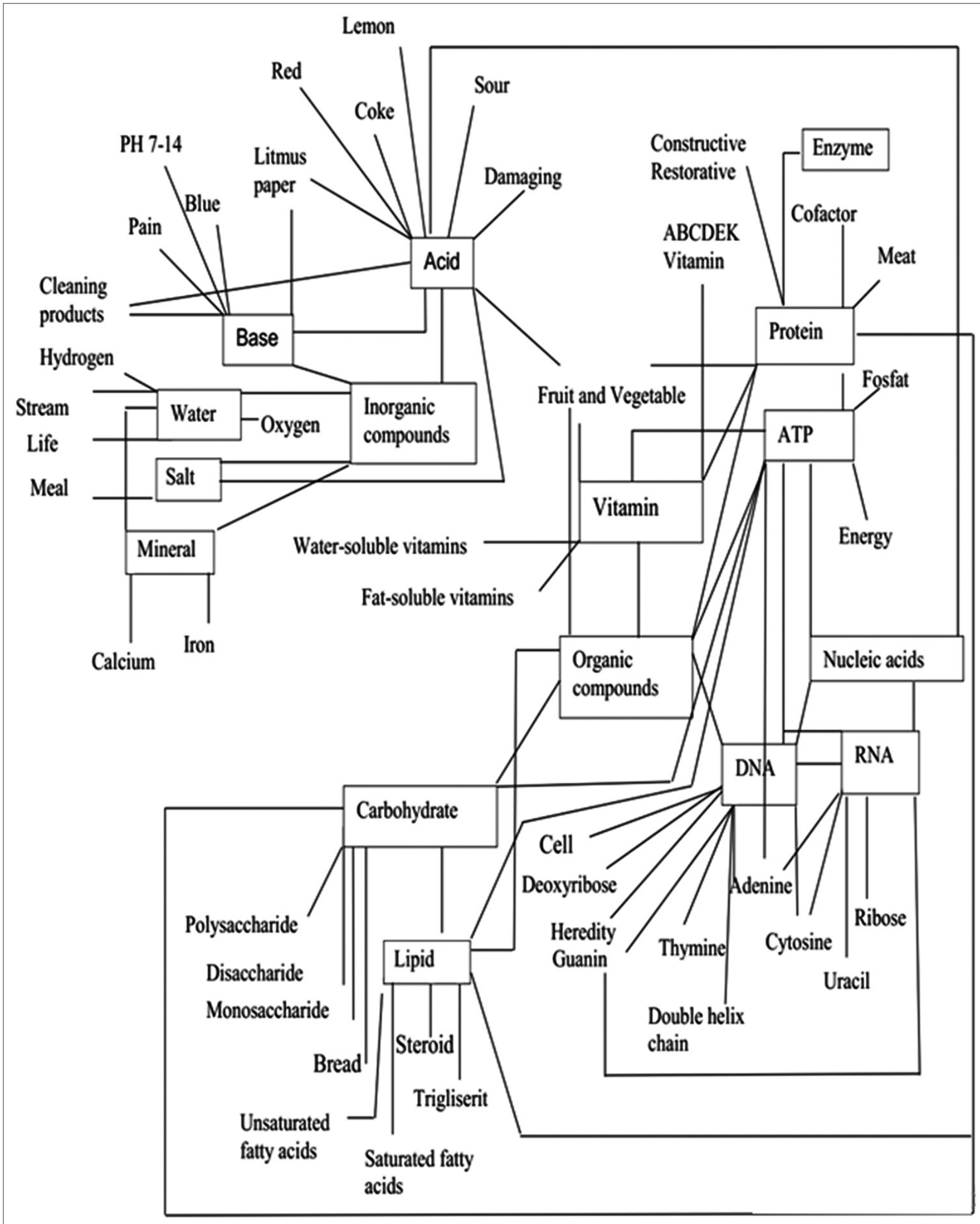

Figure 5: Mind map according to breakpoint 10-14

enzyme which was formed in the students' general cognitive structure was not strong enough. Here unscientific connections such as ATP-RNA, ATP-vitamin, and ATP-nucleic acid were also encountered. 


\section{Table 2: Results of questionnaire of writing sentence about basic components of living organisms}

\begin{tabular}{|c|c|c|c|c|c|}
\hline Theme & Sub-theme & $f$ & Theme & Sub-theme & f \\
\hline \multirow[t]{10}{*}{ 1. Inorganic compounds } & Mineral & 18 & 2. Organic compounds & Carbohydrate & 16 \\
\hline & Acid & 13 & & Protein & 16 \\
\hline & Base & 13 & & Fat & 14 \\
\hline & Water & 13 & & Vitamin & 9 \\
\hline & Salt & 11 & & Substance produced by organisms & 7 \\
\hline & Substance synthesized in organism & 11 & & Nucleic acids & 6 \\
\hline & Substance readily available in nature & 5 & & ATP & 4 \\
\hline & Inorganic substance & 2 & & Enzyme & 4 \\
\hline & & & & DNA & 2 \\
\hline & & & & RNA & 2 \\
\hline \multirow[t]{10}{*}{ 3. Acid } & $\mathrm{pH}<7$ & 19 & 4. Base & Cleaning materials & 18 \\
\hline & Fizzy drinks & 18 & & $\mathrm{pH}>7$ & 17 \\
\hline & Harmful substance & 18 & & Litmus paper & 15 \\
\hline & Litmus paper & 15 & & Bitter taste & 13 \\
\hline & Red color & 14 & & Blue color & 13 \\
\hline & Sour taste & 14 & & Making hands slippery & 10 \\
\hline & Acidic fruit and vegetable & 10 & & Hydroxyl ion & 8 \\
\hline & Hydrogen ion & 8 & & Substance ionizing in water & 5 \\
\hline & Ionization in water & 5 & & Inorganic compounds & 1 \\
\hline & Cleaning material & 3 & & & \\
\hline \multirow[t]{11}{*}{ 5. Mineral } & Elements such as iodine and iron & 17 & 6. Salt & Usage in meals & 15 \\
\hline & Necessary for health & 16 & & Acid-base reaction & 10 \\
\hline & Disease formation when a mineral & 7 & & $\mathrm{NaCl}$ & 8 \\
\hline & deficiency & 6 & & Substance necessary for Health & 6 \\
\hline & Regulatory & 6 & & Water & 6 \\
\hline & Vital events & 4 & & Table salt & 5 \\
\hline & Increasing body resistance & 2 & & Harmful in excess & 4 \\
\hline & Inorganic compounds & & & Neutral substance & 3 \\
\hline & & & & White color & 2 \\
\hline & & & & Inorganic compound & 2 \\
\hline & & & & Iodine & 1 \\
\hline \multirow[t]{10}{*}{ 7. Water } & Source of life & 25 & 8. Carbohydrate & Carbohydrate foods & 33 \\
\hline & $\mathrm{H}_{2} \mathrm{O}$ & 14 & & Energizing & 19 \\
\hline & Live & 7 & & Monosaccharide & 17 \\
\hline & Necessary for health & 7 & & Disaccharide & 14 \\
\hline & Pure and liquid substance & 6 & & Polysaccharide & 10 \\
\hline & Regulatory & 4 & & Dehydration & 4 \\
\hline & Mineral & 4 & & $\mathrm{C}, \mathrm{H}$, and $\mathrm{O}$ atoms & 3 \\
\hline & Inorganic compounds & 3 & & Kilo & 2 \\
\hline & Structure unit & 3 & & Life & 2 \\
\hline & Sweating & 1 & & & \\
\hline \multirow[t]{13}{*}{ 9. Fat } & Energy & 16 & 10. Vitamin & Water soluble & 25 \\
\hline & Saturated fatty acids (solid) & 12 & & Fat soluble & 25 \\
\hline & Unsaturated fatty acids (liquid) & 11 & & Fruit and vegetable & 14 \\
\hline & Protection & 11 & & $\mathrm{~A}, \mathrm{~B}, \mathrm{C}, \mathrm{D}, \mathrm{E}$, and $\mathrm{K}$ Vitamins & 11 \\
\hline & Human body & 10 & & Energizing & 11 \\
\hline & Harmful in excess & 5 & & Important for human & 10 \\
\hline & Kilo & 5 & & Urine disposal of surplus & 7 \\
\hline & Fat types & 4 & & Disease formation & 6 \\
\hline & Hibernation & 3 & & Regulatory & 6 \\
\hline & Carbohydrates & 3 & & Increasing body resistance & 5 \\
\hline & Storage substance & 2 & & Daily need & 3 \\
\hline & Glycerol, triglycerides & 2 & & Storage & 3 \\
\hline & Fatty acids & 2 & & & \\
\hline
\end{tabular}




\begin{tabular}{|c|c|c|c|c|c|}
\hline Theme & Sub-theme & $f$ & Theme & Sub-theme & $f$ \\
\hline \multirow[t]{16}{*}{ 11. Protein } & Energizing & 15 & 12. Enzyme & Biochemical events & 12 \\
\hline & Food with protein & 15 & & Substrate & 10 \\
\hline & Disease formation & 8 & & Synthesizing within cell & 7 \\
\hline & Constructive, regenerative & 8 & & Coenzyme & 6 \\
\hline & Regulatory & 5 & & Cofactor & 5 \\
\hline & Amino acids & 3 & & A lock and key relationship & 5 \\
\hline & $\mathrm{C}, \mathrm{H}, \mathrm{O}, \mathrm{N}$ with $\mathrm{S}$ and $\mathrm{P}$ atoms & 2 & & Liquids such as saliva and gastric & 5 \\
\hline & Organic compound & 2 & & fluids & 4 \\
\hline & & & & Protein & 3 \\
\hline & & & & Biological catalysts & 3 \\
\hline & & & & Water & 2 \\
\hline & & & & Reversible characteristic & 2 \\
\hline & & & & Simple enzyme & 2 \\
\hline & & & & Compound enzyme & 1 \\
\hline & & & & Activation energy & 1 \\
\hline & & & & Apoenzyme & \\
\hline \multirow[t]{14}{*}{ 13. Nucleic acids } & DNA & 6 & 14. DNA & Thymine & 33 \\
\hline & RNA & 5 & & Adenine & 30 \\
\hline & Adenine & 5 & & Double helix chain & 30 \\
\hline & Thymine & 5 & & Guanine & 28 \\
\hline & Cytosine & 5 & & Cytosine & 28 \\
\hline & Phosphate & 5 & & Gene & 17 \\
\hline & Guanine & 4 & & Genetic information & 15 \\
\hline & Nucleotide & 4 & & Deoxyribose & 11 \\
\hline & Carbohydrate & 4 & & Master molecule & 7 \\
\hline & Uracil & 3 & & Self-replication & 5 \\
\hline & Master molecule & 2 & & RNA & 3 \\
\hline & Deoxyribose & 2 & & ATP & 3 \\
\hline & Organic base & 2 & & Phosphate & 2 \\
\hline & & & & Chromosome & 1 \\
\hline \multirow[t]{11}{*}{ 15. RNA } & Uracil & 15 & 16. ATP & Energy & 13 \\
\hline & Ribose sugar & 13 & & Phosphate & 8 \\
\hline & Single-chain & 12 & & Cell & 8 \\
\hline & RNA varieties & 11 & & Live & 8 \\
\hline & DNA & 10 & & Adenine nucleotide & 3 \\
\hline & Adenine & 9 & & Mitochondrion & 2 \\
\hline & Guanine & 9 & & Uracil & 1 \\
\hline & Cytosine & 8 & & ADP & 1 \\
\hline & Ribosome & 1 & & & \\
\hline & Nucleotide & 1 & & & \\
\hline & Protein synthesis & 1 & & & \\
\hline
\end{tabular}

\section{Findings about QWS}

The findings from the QWS are presented in Table 2.

As seen in Table 2, the variance of the sub-themes which was most frequently seen in the students' cognitive structures about the concepts of the basic components of living organisms was listed as follows:

- Mineral in the theme inorganic compounds (18);

- Carbohydrate and protein in the theme organic compounds $(16,16) ; \mathrm{pH}<7$, fizzy drinks and harmful substance in the theme acid $(19,18,18)$;

- Cleaning materials (soap, shampoo, etc.) and $\mathrm{pH}>7$ in the theme base $(18,17)$;
- Elements in the theme mineral (iodine, iron, and calcium) and necessary for health $(17 ; 16)$;

- The usage in meals in the theme salt (15);

- Source of life in the theme water (25);

- Starchy foods (potatoes, bread, etc.) in the theme carbohydrate (33);

- Energy in the theme fat (16);

- Water soluble and fat soluble in the theme vitamin $(25,25)$;

- Energizing and food with protein (meat, meat products, egg, etc.) in the theme protein $(15,15)$;

- Biochemical events and substrate in theme enzyme $(12,10)$; 
- $\quad$ DNA in the theme nucleic acids (6);

- Thymine in the theme DNA (33); uracil in the theme RNA (15);

- $\quad$ Energy in the theme ATP (13).

Moreover, sub-themes which were related to acid, base, salt, and water themes in the students' cognitive structures were thought to be connected to the students' prior experiences and their experimental studies. Likewise, the fact that the concepts that take place in sub-themes related to carbohydrate and protein themes were associated with foods supported the effect of experience. On the other hand, the students regarded elements as minerals as in the examples of iodine, iron, and calcium. This situation points out a structure that was not correct scientifically. The statements "most of the minerals in living structure are present in the shape of mineral salts" were not encountered in the students' cognitive structures. The fact that the students used the theme vitamin with energizing (6), theme DNA with ATP (3), and theme ATP with uracil pointed out unscientific connections.

\section{DISCUSSION AND CONCLUSIONS}

\section{Results about WAT}

According to the WAT findings, the students' knowledge of total number of words about basic components of living organisms was more than the total variety of words. From this, we can conclude that the students generally associated the key words with similar concepts but the connections with these key words were not enough. The number and variety of the words which were associated with one concept showed the complexity of these concepts' relationships with other concepts and parallels with the meaningful knowledge of these words.

According to findings of the mind maps, the strong associations with the key words happen between the concepts, which are related with life, for example, vitamins-fruits and vegetables, salt-meal, water-life, water-river, base-cleaning products, acidlemon, protein-meat, and meat products, carbohydrate-bread. There are similarities between these findings and the findings of the Bahar and Özatlı's (2003) study such as water-beverage, vitamin-fruit, vitamin-protein, acid-cola, and DNA-test. There is an effect due to students' previous experiences and life while forming these relations. According to Ausubel's (1968) meaningful learning theory, to make meaningful learning it is needed for associations of new information with the old information. Meaningful learning happens thanks to these relations between words as a whole. In addition, the factors such as people's prior knowledge, experiences, thoughts, and perceptions are used in learning processes actively (Ivie, 1998).

A meaningful and scientific relationship was seen between the concepts such as nucleic acid-DNA-RNA, DNAbase of guanine-thymine-adenine-cytosine, RNA-base of adenine-cytosine-ribose-uracil, organic component-vitaminDNA-ATP-fat-carbohydrate, carbohydrate-disaccharide, monosaccharide-polysaccharide, and fat-steroid. The number of associations and complexity of them demonstrated how these concepts were constructed cognitively. However, there were still some deficiencies in the students' cognitive structures and there were some inefficacies in terms of power of associations between the concepts.

This situation might come out because of the fact that some connections could not be established between key concepts and the concepts that are needed for each key concept. For instance, only one association was established related to the concept enzyme. Similar results were observed in the study of Bahar et al. (1999), Bahar and Özatlı (2003), Sezen and Çimer (2009), Uzun et al. (2010). For example, Bahar and Özatlı (2003) indicated that the associations like enzyme-cofactor that is needed to be formed in a student's cognitive structures were not established. These findings suggest that some problems are experienced in the form of associations between concepts that are necessary for meaningful learning.

On the other hand, the students establish the associations between some unscientific concepts such as DNA-ATP, ATP-RNA, vitamin-energy, and inorganic compound mineral (calcium and iron elements). The strongest unscientific associations here actualize between ATP-DNA-RNA and inorganic compound-mineral (calcium and iron elements). These findings resemble the unscientific associations such as DNA-RNA-ATP and energy-vitamin obtained from another research study by Bahar and Özatl1 (2003). The students regarded the elements such as calcium and iron as minerals and inorganic compounds. These results point out a cognitive structure that is not valid scientifically. Because minerals are substances that are derived from elements and have proper internal structure, their own chemical combination, crystal shapes, and physical properties. Elements form minerals in the shape of inorganic compounds instead of pure elements (Şahin, Ağrıl1, Koşun, and Mengi, 2008). As a reason for this situation, the fact that this detail was not enough taken into consideration could that during the teaching of minerals and salts in the unit the students formed inadequate or wrong cognitive structure which they constructed in chemistry course. Kempa (1991) indicated that the inadequate, wrong or lack associations in students' cognitive structures might cause problems in their future learning.

\section{Results about QWS}

According to these results, meaningful and scientific concepts were used for each key concept in the students' sentences, for example, mineral for the inorganic compound, carbohydrate, and protein for organic compound, energy for fat, solution in oil and water for vitamin, thymine for DNA, uracil for RNA, and energy for ATP.

Some strong associations that existed in the mind maps prepared according to the WAT were used actively in the students' sentences written in their questionnaires. On the other hand, more concepts than the ones in the WAT were used in the students' sentences. One reason of these is that even though strong associations existed in mind maps weak associations might be seen. As Lee et al. (2001) stated that 
even if the students have enough prior knowledge about the concepts, the associations between the concepts might not be formed adequately. Even in some research on revealing the cognitive structure, the fact that the associations between all concepts are not visible in mind maps stems from both the deficiency of connections between concepts and concepts not being strong enough. For example, Bahar and Özatlı (2003) claimed that association between the concepts such as nucleic acid-DNA-RNA and energy-ATP did not occur. Uzun et al. (2010) mentioned that meaningful association between the concepts biodiversity was not formed adequately and meaningless associations exist there.

Some concepts related to the students' experiences and school life, healthy, and balanced nourishment were found. For example, $\mathrm{pH}<7$, cola and soda water for the concept acid, soap, and shampoo cleaning products for the concept base, $\mathrm{pH}>7$ and litmus paper, weight for the concept carbohydrate, necessary substance, and harmful matter when used with overdose for the concept salt, life source for the concept water, fruit and vegetable for the concept vitamin, and illnesses when it is lack of and increasing body immunity, meat, and meat products for the concepts protein and eggs. The reason of this might be the fact that the students are often taught these subjects in both biology and hygiene courses and their lives.

As an example for this, the strongest relationship in the mind maps was established between vitamin-fruit and vegetable. The importance of fruits and vegetables in healthy nourishment and the fact that they are the most important source of the vitamin are frequently emphasized in both biology and hygiene courses. Thus, it is very important that the courses, which have parallel subjects, should be taught in a way in which they will support each other. These results resemble the findings such as salt-meal, Vitamin-A, B, C, D, E, and K, base-litmus paper, acid-litmus, acid-cola, vitamin-coke, vitamin-medicine, waterlife, water-sea, water-need, water-enzyme, DNA-blood, DNAtest, water-drink, vitamin-fruit, and coke-acid. This situation supports the idea that the interaction of individuals with the environment and their prior knowledge and perception in their minds, their experiences and thoughts are effective factors on meaningful learning (Kılıç, 2001; Demirbaş and Ertuğrul, 2014; Durmuş, 2001; Stears and Gopal, 2010; Şimşek, 2004).

In the results of both the WAT and QWS, the cognitive structure related to acid and base key concepts was really improved in terms of concepts and relationships between concepts. The students' learning related to the subject acid and base were thought to occur generally in science and technology courses at school through experiment and observation. For this reason, the students' experiences related to the concept or subject need to be increased for their cognitive structures to be formed in adequate level.

In addition, some associations such as DNA-ATP and ATPuracil between unscientific concepts were encountered in the students' cognitive structures. Bahar and Özatlı (2003) detected some unscientific associations such as DNA-ATP, RNA-ATP, vitamin-energy, mineral-vitamin, carbohydrate-air, RNA-test, and water-energy.

As a result, some deficiencies, incomplete, and unscientific relationships in the formation of the students' cognitive structure about the basic components of living things have been identified. Subjects related to healthy and balanced diet in daily life and prior knowledge of ecology, health course, and other courses have been found to be effective during the development process of the student's cognitive structures. Therefore, teaching concepts associated with daily life and other disciplines, and doing practical work may be useful for meaningful learning and may provide an opportunity for students to experience learning by doing.

In biology education, a well-constructed cognitive structure is quite important for meaningful learning to occur. At the end of meaningful learning, knowledge network becomes more complex, and remembering knowledge actualizes more easily with the increase of the associations between concepts. The problems that may occur in the cognitive structure might affect their future learning negatively. Teaching methods and techniques that address unscientific statements, eliminate deficiencies, and indicate students' current cognitive structures in biology education need to be used. For this situation, the learning and teaching atmosphere needs to be focused on student-centered teaching in which students are able to interact socially, study in cooperation, take an active role in the period of teaching and learning, learn by doing, and living (Zeki and Güneyli, 2014). Cooperative learning, concept maps, education based on problems, education centered on projects, researchinformed education, teaching using experiments, and a variety of teaching methods, and techniques are recommended.

It should be pointed out that not only are the previously mentioned methods and techniques more likely to be effective but also factors such as real life, other disciplines, topics, and concepts are effective in shaping students' cognitive structure.

\section{REFERENCES}

Adıgüzel, A. (2009). Yenilenen ilköğretim programının uygulanmas1 sürecinde karşılaşılan sorunlar (The problems encountered during the application of the new primary education program). Mehmet Akif Ersoy Üniversitesi Eğitim Fakültesi Dergisi, 9(17), 77-94.

Atasoy, B. (2004). Fen Eğitimi ve Öğretimi (Science Education and Teaching). Ankara: Gündüz Education and Publishing.

Ausubel, D.P. (1968). Educational Psychology a Cognitive View. New York, NY: Holt, Rinehart and Winston, Inc.

Baddeley, A. (1992). Working memory. Science, New Series, 255(5044), 556-559.

Kılıç, G.B. (2001). Oluşturmacı fen öğretimi (Constructivist science teaching) Kuram ve Uygulamada Eğitim Bilimleri Dergisi. Journal of Educational Sciences: Theory and Practice, 1(1), 7-22.

Bahar, M., \& Özatlı, S. (2003). Kelime iletişim test yöntemi ile lise 1. sınıf öğrencilerinin canlıların temel bileşenleri konusundaki bilişsel yapılarının araştırılması (Study on the cognitive structures of the $1^{\text {st }}$ grade high school students related to the basic components of organisms via the word association test method). Ballkesir University Institute of Physical Sciences Journal, 5, 75-85.

Bahar, M., \& Tongaç, E. (2009). The effect of teaching approaches on the pattern of pupils' cognitive structure: Some evidence from the field. The 
Asia-Pacific Education Researcher, 18(1), 21-45.

Bahar, M., Johnstone, A.H., \& Sutcliffe, R.G. (1999). Investigation of students' cognitive structure in elementary genetics through word association tests. Journal of Biological Education, 33, 134-141.

Bahar, M., Nartgün, Z., Durmuş, S., \& Bıçak, B. (2006). Geleneksel Ve Alternatif Ölçme Ve Değerlendirme Öğretmen El Kitabı (Traditional Measurement and Evaluation Teacher's Handbook). Ankara: Pegem-A Publishing.

Büyüköztürk, Ş., Çakmak, E.K., Akgün, E., Karadeniz, Ş., Demirel, F. (2013). Scientific Research Methods. $8^{\text {th }}$ ed. Ankara: Pegem Akademi.

Çardak, O. (2009). Students' ideas about dangerous animals. Asia-Pacific Forum on Science Learning and Teaching, 10(2), 8.

Demirbaş, M., \& Ertuğrul, N. (2014). A study on preschoolers' conceptual perceptions of states of matter: A case study of Turkish students. South African Journal of Education, 34(3), 01-13.

Durmuş, S. (2001). Matematik öğretiminde oluşturmacı yaklaşımlar (Constructionist approaches to mathematics teaching). Journal of Educational Sciences in Theory and Practice, 1(1), 91-107.

Ercan, F., Taşdere, A., \& Ercan, N. (2010). Kelime ilişkilendirme testi aracılığıyla bilişsel yapının ve kavramsal değişimin gözlenmesi (Observation of cognitive structure and conceptual changes through word associations tests). Journal of Turkish Science Education, 7(2), 155-157.

Gulacar, O., Sinan, O., Bowman, C.R., \& Yildırım, Y. (2014). Exploring the changes in students' understanding of the scientific method using word associations. Research in Science Education, 45(5), 1-10.

Gussarsky, E., \& Gorodetsky, M. (1988). On the chemical equilibrium concept: Constrained word associations and conception. Journal of Research in Science Teaching, 25(5), 319-333.

Ivie, S.D. (1998). Ausubel's learning theory: An approach to teaching higher order thinking skills (Educational psychologist David Paul Ausubel). High School Journal, 35(1), 35-42.

Kempa, R.F., \& Nicholls, C.E. (1983). Problem solving ability and cognitive structure an explanatory investigation. European Journal of Science Education, 5, 171-184.

Kempa, R.F. (1991). Students' learning difficulties in science. Causes and possible remedies. Enseñanza de las Ciencias, 9(2), 119-128.

Kırbaş, A., \& Orhan, S. (2011). Görsel materyallerle desteklenmiş yazma çalışmalarının öğrencilerin yazma becerilerini geliştirmeye etkisi (The effect of writing exercises supported by visual materials on the development of writing skills). Turkish Studies-International Periodical for The Languages, Literature and History of Turkish or Turkic, 6(4), 705-714.

Kurt, H. (2013). Biology student teachers' cognitive structure about "living thing". Educational Research and Reviews, 8(12), 871-880.

Kurt, H., Ekici, G., Aksu, Ö., \& Aktaş, M. (2013). The most important concept of transport and circulatory systems: Turkish biology student teachers' cognitive structure. Educational Research and Reviews, 8(17), 1574-1593.

Lee, K.W.L., Tang, W.U., Goh. N.K., \& Chia L.S. (2001). The predicting role of cognitive variables in problem solving in mole concept. Chemistry Education: Research and Practice in Europe, 2(3), 285-301.

Nakiboğlu, C. (2008). Using word associations for assessing non major science students' knowledge structure before and after general chemistry instruction: The case of atomic structure. Chemistry Education Research and Practice, 9, 309-322.

Onan, B. (2012). Türkçenin ana dili olarak öğretiminde bilgi işleme süreci (Data Processing Process in the Teaching of Turkish as a Mother Tongue). Mersin University Journal of the Faculty of Education, 8(1), 96-113.

Yücel, E.O., \& Özkan, M. (2015). Determination of secondary school students' cognitive structure, and misconception in ecological concepts through word association test. Educational Research and Reviews, $10(5), 660-674$

Özatlı, N.S. (2006). Öğrencilerin Biyoloji Derslerinde zor Olarak Algıladıkları Konuların Tespiti ve Boşaltım Sistemi Konusundaki Bilişsel Yapılarının Yeni Teknikler ile Ortaya Konmast (Determination of the Subjects Students Have Difficulty in Understanding in Biology Lessons and Establishment of the Cognitive Structures about Urinary System Via New Techniques). PhD Thesis. Balıkesir: Balıkesir University.

Perker, Z.S. (2011). Mimarlık öğrencilerinin malzeme bilgisinin arttırılmasında fabrika gezilerinin rolü: Metodolojik bir analiz (The role of factory visits in the material knowledge enhancement of architecture students: A methodological analysis). SAÜ. Journal of Physical Sciences, 15(1), 82-88.

Ring, D.G., \& Novak, J.D. (1971). The effects of cognitive structure variable on achievement in college chemistry. Journal of Research in Science Teaching, 8(4), 325-333.

Şahin, M.B., Ağrılı, H., Koşun, E., \& Mengi, H. (2008). Minerals. Ankara: General Directorate of Mineral Research and Exploration Periodicals.

Schizas, D., Katrana, E., \& Stamou, G. (2013). Introducing network analysis into science education: Methodological research examining secondary school students' understanding of 'decomposition'. International Journal of Environmental and Science Education, 8(1), 175-198.

Schunk, D.H. (2009). Öğrenme Teorileri-eğitimsel bir Bakuş (Theories of Learning-an Educational Perspective). (Translated by: Ed. Muzaffer Şahin). Ankara: Nobel Publishing Distribution.

Sezen, G., \& Çimer, A. (2009). Fen Bilgisi Öğretmen Adaylarının Insanda Dolaşım Sistemi Konusundaki Kavramlart Anlama Seviyelerinin Kavram Haritası ve Kelime Ilişkilendirme Testi ile Belirlenmesi (Determination of science teacher candidates' comprehension level of the concepts related to the circulatory system in humans via concept map and word association test). Uluslararası Eğitim Araştırmaları Kongresi ( $1^{\text {st }}$ International Educational Research Congress), Çanakkale: Çanakkale On Sekiz Mart University.

Şimşek, N. (2004). Yapılandırmacı öğrenme ve öğretime eleştirel bir bakış (A critical perspective on constructivist learning and teaching). Educational Sciences and Application, 3(5), 115-139.

Sinan, O., Yıldırım, O., Kocakülah, M.S., \& Aydın, H. (2006). Fen bilgisi ögrretmen adaylarının proteinler, enzimler ve protein sentezi ile ilgili kavram yanılgıları (Misconceptions of science teacher candidates on proteins, enzymes and protein synthesis). Journal of Gazi Faculty of Education, 1(26), 1-16.

Solaz-Portolés, J.J., \& Lopez, V.S. (2007). Representations in problem solving in science: Directions for practice. Asia-Pacific Forum on Science Learning and Teaching, 8(2), 1-17.

Solso, L., Maclin, M.K., \& Maclin, O.H. (2009). Cognitive Psychology. (Translated by: Ayşe Ayçiçeği Dinn). İstanbul: Kitapevi Publishing.

Stears, M., \& Gopal, N. (2010). Exploring alternative assessment strategies in science classrooms. South African Journal of Education, 30(4), 591-604.

Tongaç, E. (2006). Farklı Öğretim Yaklaşımlarının Öğrencilerin fen Bilgisi Dersi Dolaşım Sistemi Konusundaki Bilişsel Yapılarına Etkilerinin Araştırlmast (A study on The Effects of Different Teaching Approaches on the Cognitive Structures of Students about the Science Lesson Circulatory System). Unpublished Master's Thesis. Bolu: AİBU, Institute of Social Sciences.

Tsai, C.C. (1998). An analysis of Taiwanese eighth graders' science achievement, scientific epistemological beliefs and cognitive structure outcomes after learning basic atomic theory. International Journal of Science Education, 20(4), 413-425.

Uzun, N., Özsoy, S., \& Keleş, Ö. (2010). Opinions of teacher candidates on the concept of biological diversity. Journal of Biological Sciences Research, 3(1), 93-99.

White, R., \& Gunstone, R. (1992). Probing Understanding. London: The Falmer Press.

Yıldırım, A., \& Şimşek, H. (2006). Sosyal Bilimlerde Nitel Araştırma Yöntemleri (Qualitative research methods in social sciences). Ankara: Seçkin Publishing.

Zan, N., Zan, B.U., \& Morgil, F.İ. (2015). The word cloud illustration of the cognitive structures of teacher candidates about education concept. Smart Education and Smart e-Learning, 41, 357-370.

Zeki, C. P., \& Güneyli, A. (2014). Student teachers' perceptions about their experiences in a student centered course. South African Journal of Education, 34(3), 1-7. 


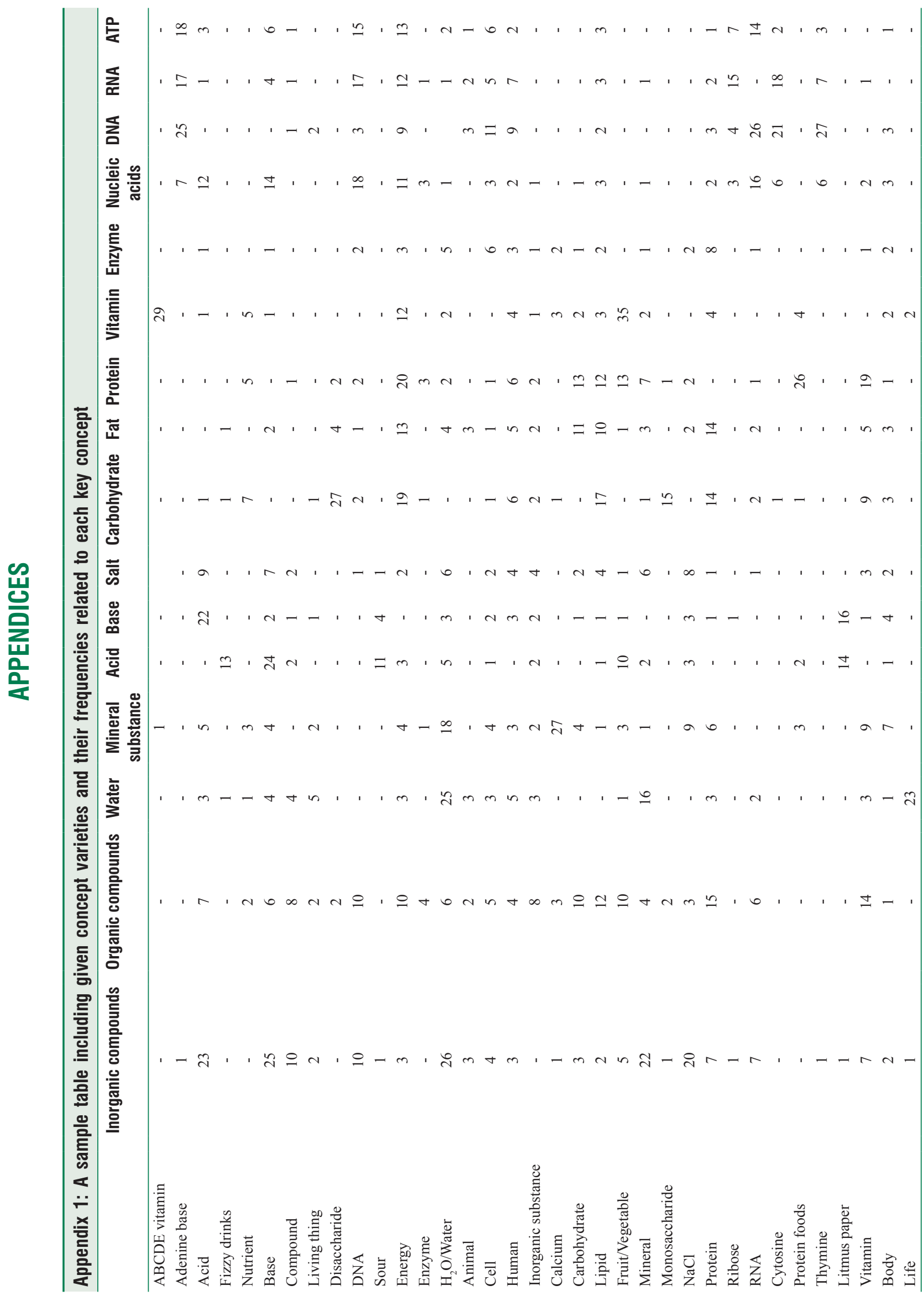




\section{Appendix 2: A sample answer paper of a student to word association test and questionnaire of writing sentence}

Orgatik Bilengik

Organikbilegik Vițonin

Organilk bilesile Protein

Organikbilesik Megy ..............................

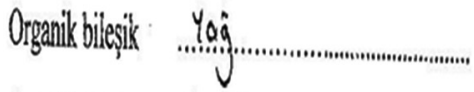

Orgạilikbilesilu insson

Organaik bileşik Hịice

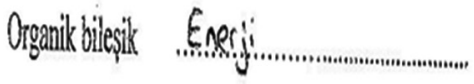

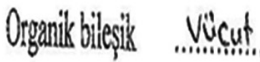

Oiganik bilegik Bi...t.

Orgailkbileyik R R N

cumbe: Conllior farofindon irelebilen vitamin, proten, yog gobi
Organic Compound

Organic compound Vitamin

Organic compound Protein

Organic compound Fruit

Organic compound Lipid

Organic compound Human

Organic compound Cell

Organic compound Energy

Organic compound Body

Organic compound Plant

Organic compound RNA

Sentence: They are compounds that can be produced by living organism such as vitamin, protein, and lipid

bileģikif. 